Gut, 1967, 8, 64

\title{
Mastocytosis (urticaria pigmentosa) of skin, stomach, and gut with malabsorption ${ }^{1}$
}

\author{
STIG JARNUM AND HUGH ZACHARIAE \\ From the Department of Dermatology and Venereology and Medical Department $P$, \\ Division of Gastroenterology, Rigshospitalet, Copenhagen, Denmark
}

EDITORIAL COMMENT It is postulated that excess production of histamine in this patient with urticaria pigmentosa gave rise to the malabsorption syndrome. A most interesting case history.

Skin changes are frequently seen in malabsorption (Wells, 1962; Cooke, 1952) and pigmentation occurs in a great many cases of steatorrhoea (Badenoch, 1960; Simpson, 1954). No data, however, have been presented indicating any common agent being responsible for the symptoms from both skin and the gastrointestinal tract. In systemic mast cell disease gastrointestinal symptoms occur in about half the cases (Mutter, Tannenbaum, and Ultmann, 1963). Abdominal pains, nausea, and diarrhoea are the usual complaints, whereas malabsorption in the exact meaning of the term has been only infrequently reported (Janower, 1962; Bank and Marks, 1963).

This paper describes a case of the telangiectatic type of urticaria pigmentosa (telangiectasia macularis eruptiva perstans) (Weber and Hellenschmied, 1930) with malabsorption and increased amounts of mast cells and histamine in skin, stomach, and gut.

\section{CASE REPORT}

The patient was a 40-year old housewife who was first admitted to this hospital in February 1965 because of malabsorption and hypocalcaemia.

The family history contributed nothing.

Dyspeptic symptoms with constipation developed when she was 15 years old. Ever since, she has suffered from periodical abdominal pain, usually after meals. When she was 30, 'too much acid' was present in a gastric aspirate following a test meal, but it was not until 1960, when she was 36 , that she was admitted to hospital for dyspepsia. Radiographs of the stomach, gall bladder, and colon were normal. The only abnormal findings were eosinophilia ( 775 per $\mu$ l.) and an extensive brown macular pigmentation which left free only her face and neck, and which she contracted during her only pregnancy 14 years earlier at an age of 22 years. A diagnosis of urticaria

${ }^{1}$ This work was supported by Købmand i Odense Johan Weymann og Hustru, født Seedorff's Fund and by a National Institutes of Health foreign grant (7 ROS TW-00 157-01) to one of the authors (S.J.). pigmentosa and asthenia was made. She was dismissed on symptomatic treatment with anticholinergic drugs and remained well during the next few years.

In 1963, diarrhoea developed, together with lower right abdominal pain which she had not experienced before. The stools were light yellow, sometimes watery, but not fatty.

From October 1964 diarrhoea increased in frequency and she started to vomit now and then. Mild tetanic attacks developed with paraesthesia of the fingers and 'cramps' in the arms and fingers. Her distress and the symptoms mentioned grew steadily worse. Her body weight decreased about $4 \mathrm{~kg}$. in six months. Finally she had daily attacks of tetany and was admitted to hospital in January 1965. On physical examination she had typical carpopedal spasms. Low serum concentrations were found of calcium $(5.9 \mathrm{mg} . / 100 \mathrm{ml}$.), magnesium $(0.8$ $\mathrm{mEq}$./1.), and potassium (2.3 $\mathrm{mEq}$./1.). A marked eosinophilia was present $(1,488 / \mu \mathrm{l}$.).

She responded well to treatment with calcium and potassium. Furthermore, she received pancreatin and a diet containing a restricted amount of fat. Because of steatorrhoea, an abnormal radiograph of the small intestine, and a flat blood sugar curve during an oral glucose tolerance test (maximum rise to $125 \mathrm{mg} . / 100 \mathrm{ml}$.), she was transferred to this hospital five weeks after the first admission.

Physical examination showed a slightly pale and emaciated woman whose general condition was fairly good. There was no sign of latent tetany. Chvostek's and Trousseau's signs were negative. The abdomen was normal as was a pelvic examination.

The skin showed an extensive eruption on the trunk and limbs consisting of numerous brownish-red macules and lesions of superficial telangiectasia (Fig. 1). There was pronounced dermographism of the urticarial type.

Blood pressure was $100 / 80 \mathrm{~mm} . \mathrm{Hg}$, the pulse rate $80 /$ minute, and the electrocardiogram was normal.

Radiographs of the chest, cranium, lumbar spine, humeri and femora, oesophagus, stomach, and colon were normal. The small intestine showed a coarse mucosal pattern in the duodenum and the proximal jejunum.

Sigmoidoscopy was normal. 


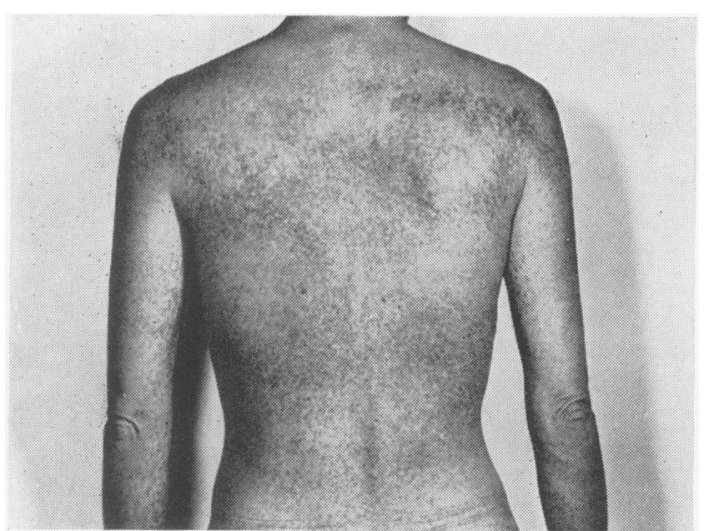

FIG. 1. Skin of the back showing numerous pigmented macules and lesions of superficial telangiectasia.

LABORATORY INVESTIGATIONS Haemoglobin concentration was slightly depressed, $11.7 \mathrm{~g} . / 100 \mathrm{ml}$., mean cell haemoglobin concentration and mean cell volume were normal ( $33 \mathrm{~g} . / 100 \mathrm{ml}$. and $95 \mathrm{mpl}$, respectively), and serum iron and total iron-binding capacity did not exceed the normal limits (95 and $317 \mu \mathrm{g} . / 100 \mathrm{ml}$., respectively). Erythrocyte sedimentation rate was $4 \mathrm{~mm}$. in one hour. Leucocytes numbered $4,100 / \mathrm{ml}$. with moderate eosinophilia and an otherwise normal differential count. Thrombocytes numbered $350,000 / \mu 1$. The eosinophil count was almost consistently elevated (331 to $1,300 / \mu \mathrm{l}$.). Bleeding and clotting times were normal. A sternal aspirate contained normoblastic marrow with some eosinophilia and an increased number of mast cells.

Serum electrolytes Serum potassium (3.2 mEq./1.) and magnesium $(1 \cdot 1 \mathrm{mEq} . / \mathrm{l}$.) were moderately depressed, serum calcium normal or slightly depressed $(8.5$ to 9.5 mg./100 ml.), sodium (141 mEq./l.) and phosphorus (3.1 to $4.1 \mathrm{mg} . / 100 \mathrm{ml}$.), normal and standard bicarbonate slightly elevated $(26 \cdot 1$ to $25.0 \mathrm{mEq}$./1.).

Protein-bound iodine in serum was normal $(6 \cdot 2 \mathrm{~g} . / 100$ ml.), and the basal metabolic rate $+9 \%$.

Urinary excretion of 17-hydroxycorticosteroids was normal ( $9.6 \mathrm{mg} . / 24$ hours).

Renal function No protein or sugar was present in the urine. The sediment was normal as was serum creatinine (0.7 mg./100 ml.).

Hepatic function Serum bilirubin $(1.0 \mathrm{mg} . / 100 \mathrm{ml}$.), thymol turbidity (0.04), alkaline phosphatases (5.3 KingArmstrong units/100 ml.), glutamic acid-pyruvic acid transaminases $(0.5$ units $/ \mathrm{ml}$.) were all normal. Prothrombin was slightly depressed (74-63\% of normal).

Serum proteins Total protein was $5.8 \mathrm{~g} . / 100 \mathrm{ml}$. Paper electrophoresis revealed a slightly depressed serum albumin $(4.0 \mathrm{~g} . / 100 \mathrm{ml}$, , normal range in this laboratory: 4.44 to 5.86 g. $/ 100 \mathrm{ml}$.), gamma-globulin at the lower normal limit $(0.62 \mathrm{~g} . / 100 \mathrm{ml}$.), and normal $\alpha$ - and $\beta$-globulins.

Immunoelectrophoresis showed an increased amount of gamma $_{M}$-globulin, but normal amounts of gamma ${ }_{A}-$ and gamma $_{\mathrm{G}}$-globulins. The third component of complement was inactivated.

Paper electrophoresis was done of serum and urine (concentrated about 100 times). In both fluids a weak band with the mobility of chondroitin sulphate $B$ appeared after staining of the strips with Alcian blue.

A quantitative determination of the urinary excretion of hexosamine and glucuronic acid bound to acid mucopolysaccharides yielded normal figures. Both this analysis and the paper electrophoretic demonstration of chondroitin sulphate $B$ were made six weeks after admission at a time when a marked remission had occurred following dietary treatment.

Serum lipids were noi mal (cholesterol $164 \mathrm{mg} . / 100 \mathrm{ml}$., total esterified fatty acids $9.45 \mathrm{mEq} . / 1$.).

GASTROINTESTINAL FUNCTION TESTS The stools were yellow and fatty (fat excretion $28.6 \mathrm{~g}$./day).

Benzidine reactions were consistently negative.

Faecal calcium and magnesium were increased (see below).

A D-xylose test was normal $(7 \cdot 1 \mathrm{~g}$. excreted in 24 hours in the urine after an oral load of $25 \mathrm{~g}$.).

Serum vitamin $\mathbf{B}_{12}$ and folic acid levels were normal (410 pg. $/ \mathrm{ml}$. and $0.006 \mathrm{~g} . / \mathrm{ml}$., respectively).

Schilling's test was normal (9.9\% excreted in two days).

5-Hydrocyindole-acetic acid excretion was normal (below $10 \mathrm{mg}$. in 24 hours).

A glucose tolerance test showed a maximum rise of blood sugar to $122 \mathrm{mg}$. $/ 100 \mathrm{ml}$. A similar, flat blood sugar curve was found during a lactose tolerance test. However, the rise, $28 \mathrm{mg}$. $/ 100 \mathrm{ml}$. (from 75 to $103 \mathrm{mg}$. $/ 100$ ml.), was high enough to exclude lactose malabsorption (Haemmerli, Kistler, Ammann, Marthaler, Semenza, Auricchio, and Prader, 1965).

Pancreatic function tests were normal. The amylase concentration in duodenal aspiration rose to 172 millienzyme units per litre following secretin stimulation (normal value above 100 ).

Gastric hydrochloric acid production during an augmented histamine test was high normal (maximum: 24 mEq. $\mathbf{H}^{+}$/hour).

A ${ }^{51} \mathrm{Cr}$-albumin test was slightly abnormal, $1.48 \%$ of the label being excreted in the stools in four days (normal figure less than $1 \%$ ), which was compatible with a moderate gastrointestinal protein loss.

HISTOLOGICAL EXAMINATIONS For mast cell examination, biopsies were fixed in a $4 \%$ aqueous lead subacetate solution for 24 hours, embedded in paraffin, sectioned, and stained with 0.5 aqueous solution of toluidine blue, which rather selectively stains acid mucopolysaccharides metachromatically.

A skin biopsy revealed melanin pigmentation of the epidermal cells and numerous mast cells in the dermis. The histological diagnosis was urticaria pigmentosa.

A biopsy from the jejunum showed large amounts of mast cells in the connective tissue of the lamina propria as well as in the muscularis mucosae and submucosa. At several places they formed dense infiltrations (Fig. 2).

The villous architecture was normal as was the crypt layer. The epithelial cells showed no flattening, and their 


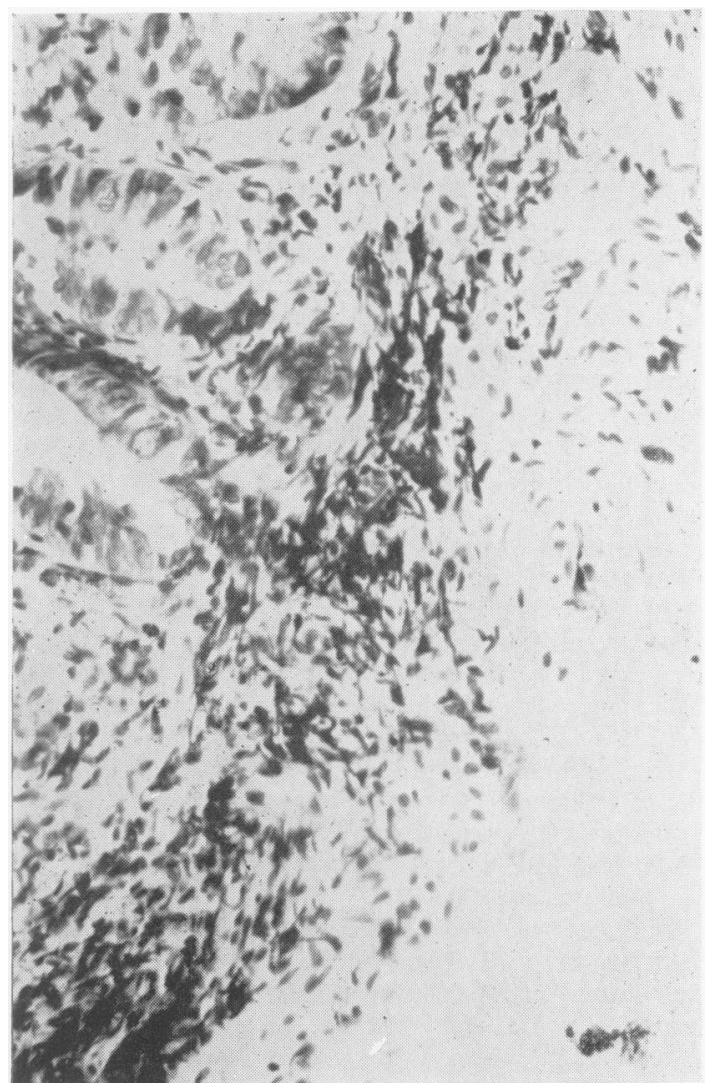

FIG. 2. Photomicrograph of biopsy from the jejunum. Note large amounts of mast cells in the connective tissue of the lamina propria. A heavy infiltration of mast cells surrounds the bottom of two crypts of Lieberkühn (toluidine blue, $0.5 \%$ aqueous).

structure did not appear abnormal on light microscopy.

Biopsy of gastric mucosa also showed an increased amount of mast cells in the connective tissue, but was otherwise normal.

A biopsy from the rectum, which was not stained for mast cells, showed a pronounced eosinophilia.

A liver biopsy was normal. Few mast cells were present. It was not stained with toluidine blue.

HISTAMINE ANALYSES Histamine determinations were performed on dried and defatted skin as well as on fresh samples of stomach and jejunal tissue by the spectrofluorometric method of assay (Shore, Burkhalter, and Cohn, 1959) according to a procedure previously described by one of the authors (Zachariae, 1964).

The results are given in Table I, which shows the histamine content of both skin, stomach, and small intestinal biopsies to be significantly elevated as compared with normal.

In one other case of urticaria pigmentosa (J.M.), who
TABLE

HISTAMINE CONTENT IN BIOPSIES

\begin{tabular}{|c|c|c|c|c|}
\hline \multirow{3}{*}{$\begin{array}{l}\text { Histamine } \\
\text { Content }\end{array}$} & \multicolumn{4}{|l|}{ Diagnosis } \\
\hline & $\begin{array}{l}\text { I.T. } \\
\text { (present } \\
\text { case) }\end{array}$ & $\begin{array}{l}\text { E.S. } \\
\text { (control) }\end{array}$ & $\begin{array}{l}\text { Normal } \\
\text { Value }\end{array}$ & J.M. \\
\hline & $\begin{array}{l}\text { Urticaria } \\
\text { pigmentation } \\
\text { and } \\
\text { malabsorp- } \\
\text { tion }\end{array}$ & Osteoporosis & & $\begin{array}{l}\text { Urticaria } \\
\text { pigmentosa } \\
\text { without } \\
\text { gastrointestinal } \\
\text { symptoms }\end{array}$ \\
\hline
\end{tabular}

Skin

( $\mu$ g./g. dried

and defatted

skin)

75.8 (thigh)

$27 \cdot 8^{1} \pm 85 \cdot 2$ (forearm)

Stomach

( $\mu$ g./g. fresh $26 \cdot 4$

tissue)

Small intestine

( $\mu$ g./g. fresh 48.4

tissue)

$6 \cdot 1$

'Standard error, Zachariae (1964).

${ }^{2}$ Stone, Merrill, and Meneely (1955).

had no clinical signs of gastrointestinal involvement and no malabsorption, an increased histamine content was also found in the small intestine.

SUBSEQUENT COURSE AND TREATMENT During the first weeks in hospital the patient received a full diet, supplying about $90 \mathrm{~g}$. fat and 2,000 kcal. per day. Her general condition improved gradually, but steatorrhoea persisted. In a three-day balance study a net loss of both calcium and magnesium was observed (Fig. 3). Faecal calcium and magnesium excretions were $1.2 \mathrm{~g}$. and $19 \mathrm{mEq}$. per day, respectively. At the same time, the serum concentrations of calcium and magnesium were only moderately depressed, $8.6 \mathrm{mg} . / 100 \mathrm{ml}$. and $1 \mathrm{mEq}$. $/ 1$., respectively.

She was placed on a low-fat diet ( 7 g. per day) supplemented with medium chain triglycerides, and the supply of calcium and magnesium was increased. A significant improvement followed the institution of this regime. Steatorrhoea diminished (from $28.6 \mathrm{~g}$. fat/day to $4 \cdot 2$ to $13 \cdot 1 \mathrm{~g}$./day), her body weight rose $5 \mathrm{~kg}$. in 10 weeks, and serum calcium, magnesium, and potassium levels became normal.

She was discharged and followed up in the out-patient clinic. After 10 weeks of treatment with medium chain triglycerides the patient resumed a full diet with moderate fat restriction. She did well on this and suffered only occasional diarrhoea. Periactin was now given as a therapeutic trial. It did not affect the degree of steatorrhoea (faecal fat was 18.6 and $24.6 \mathrm{~g}$./day before and during periactin treatment). However, she noticed that diarrhoea stopped or decreased after Periactin.

${ }^{1}$ Medium chain triglycerides were obtained from Drew Chemical Co., Boonton, New Jersey, U.S.A. 


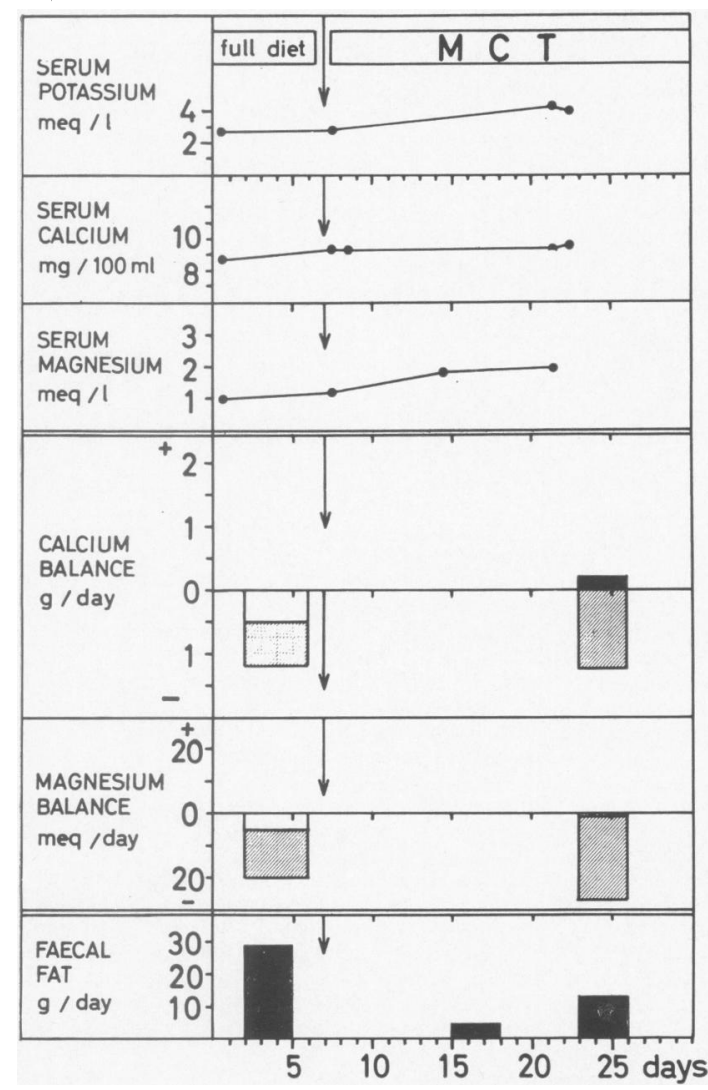

FIG. 3. Serum electrolytes, balance data for calcium and magnesium, and faecal fat excretion.

Below zero: total urinary + faecal excretion.

Hatched area: intake

Solid black: positive balance.

MCT: medium chain triglycerides (supplied by Drew Chemical Co., Boonton, New Jersey, U.S.A.)

\section{COMMENTS}

This patient with mastocytosis showed evidence of a malabsorption syndrome and increased amounts of mast cells and histamine in skin and gastrointestinal tract. Mast cells have been proven to contain considerable quantities of histamine (Riley and West, 1953) and several workers have reported high skin histamine values in urticaria pigmentosa (Sjoerdsma, Waalkes, and Weissbach, 1957; Lindell, Rorsman, and Westling, 1961; Zachariae, 1963). Histamine is considered the agent responsible for urtication (Zachariae, 1963). The histological site of histamine in the stomach (Feldberg and Harris, 1953) indicates the presence of mast cell histamine as well as non-mast cell histamine. Although it has been accepted lately that urticaria pigmentosa is not strictly limited to skin (Berlin, 1955; Reilly, Shintani, and Goodman, 1955; Asboe-Hansen, 1960), and some cases have been reported with gastrointestinal symptoms (Berlin, 1955; Brodeur and Gardner, 1956; Reilly et al., 1955; Zak, Covey, and Snodgrass, 1957), no determinations showing increased gastric and jejunal histamine seem to have been published previously.

Eosinophils, supposed to possess antihistaminic activity (Archer, 1959; Kovacs, 1950), have been found in great numbers in 'skin windows' following local injections of histamine liberators (WolfJurgensen and Zachariae, 1965) and in urticaria pigmentosa following non-specific trauma (Wulff, Zachariae, and Oehlenschlaeger, 1965). The pronounced number of eosinophils in the biopsy from the rectum of our patient indicate a histamine release.

The diarrhoea and steatorrhoea may, in part, be due to histamine. Experimentally, histamine (Dale and Laidlaw, 1910), as well as histamine liberators (Zachariae, 1964), may give rise to sensations of intestinal hypermotility and diarrhoea.

Malabsorption has been reported in the carcinoid syndrome (Nash and Brin, 1964; Melmon, Sjoerdsma, Oates, and Laster, 1965). In recent years it has become apparent that carcinoid tumours produce not only serotonin but also other biologically active substances such as histamine and kallikrein (Sjoerdsma and Melmon, 1964). In addition, serotonin is considered a potent histamine releaser (Feldberg and Smith, 1953) and serotonin antagonists may reduce malabsorption and diarrhoea in the carcinoid syndrome (Melmon et al., 1965).

The malabsorption observed in the present case was characterized by steatorrhoea and severe depression of serum calcium, magnesium, and potassium, probably due to a net loss of these electrolytes in the gut. Similar electrolyte disturbances have been reported in another case of malabsorption associated with mastocytosis (Bank and Marks, 1963). Severe tetany developed in the case described by these authors, and an excessive faecal calcium loss was demonstrated. Serum albumin was slightly depressed or normal, a finding which was also observed in the present case. Apparently, no significant plasma protein loss occurs in spite of the fact that histamine produces local oedema as it was visualized in a small intestinal series. The ${ }^{51} \mathrm{Cr}$ albumin test performed in the present case was only slightly abnormal.

\section{SUMMARY}

A case is presented of urticaria pigmentosa with mal- 
absorption and increased amounts of mast cells and histamine in skin, stomach, and gut. Histamine is considered to be the agent responsible for both urticaria of skin and small intestinal dysfunction.

\section{REFERENCES}

Archer, R. K. (1959). Eosinophil leucocytes and their reactions to histamine and 5-hydroxytryptamine. J. Path. Bact., 78, 95-103.

Asboe-Hansen, G. (1960). Urticaria pigmentosa with generalized tissue mastocytosis and blood basophilia. Arch. Derm., 81 , 198-202.

Badenoch, J. (1960). Steatorrhea in the adult. Brit. $m$ 'd. J., 2, 879-887, 963-974.

Bank, S., and Marks, I. N. (1963). Malabsorption in systemic mast cell disease. Gastroenterology, 45, 535-549.

Berlin, C. (1955). Urticaria pigmentosa as a systemic disease. Arch. Derm. 71, 703-712.

Brodeur, P., and Gardner, L. I. (1956). Urticaria pigmentosa as a problem in diagnosis. New Engl. J. Med., 354, 1165-1168.

Cooke, W. T. (1952). In Modern Trends in Gastroenterology, Series I, eited by F. Avery Jones, pp. 495-513 Steatorrhoea, p. 500 Skin rash, Butterworth, London.

Dale, H. H., and Laidlow, P. P. (1910). The physiological action of $\beta$ iminazolylethylamine. J. Physiol. (Lond.), 41, 318-344.

Ellis, J. M. (1949). Urticaria pigmentosa: report of a case with autopsy. Arch. Path., 48, 426-435.

Feldberg, W., and Harris, G. W. (1953). Distribution of histamine in the mucosa of the gastro-intestinal tract of the dog. J. Physiol. (Lond.), 120, 352-364.

- and Smith, A. N. (1953). Release of histamine by tryptamine and 5-hydroxytryptamine. Brit. J. Pharmacol., 8, 406-411.

Haemmerli, U. P., Kistler, H., Ammann, R., Marthaler, T., Semenza, G., Auricchio, S., and Prader, A. (1965). Acquired milk intolerance in the adult caused by lactose malabsorption due to a selective deficiency of intestinal lactase activity. Amer. J. Med. 38, 7-30.

Janower, M. L. (1962). Mastocytosis of the gastrointestinal tract. Report of a case. Acta radiol. (Stockh,), 57, 489-493.

Kovacs, A. (1950). Antihistaminic effect of eosinophil leucocytes. Experientia (Basel), 6, 349-350.
Lindell, S. E., Rorsman, H., and Westling, H. (1961). Histamine formation in urticaria pigmentosa. Acta derm.-venereol. (Stockh.) 41, 277-280.

Melmon, K. L., Sjoerdsma, A., Oates, J. A., and Laster, L. (1965). Treatment of malabsorption and diarrhoea of the carcinoid syndrome with methysergide. Gastroenterology, 48, 18-24.

Mutter, R. D., Tannenbaum, M., and Ultmann, J. E. (1963). Systemic mast cell disease. Ann. intern. Med., 59, 887-906.

Nash, D. T., and Brin, M. (1964). Malabsorption in malignant carcinoid with normal 5-HIAA. $N . Y$. St. J. Med., 64, 1128-1131.

Reilly, E., Shintani, J., and Goodman, J. (1955). Systemic mast-cell disease with urticaria pigmentosa. Arch. Derm., 71, 561-569.

Riley, J. F. and West, G. B. (1953). The presence of histamine in tissue mast cells. J. Physiol. (Lond.), 120, 528-537.

Shore, P. A., Burkhalter, A., and Cohn, V. H., Jr. (1959). A method for the fluorometric assay of histamine in tissues. J. Pharmacol. exp. Ther., 127, 182-186.

Simpson, J. A. (1954). Dermatological changes in hypocalcaemia. Brit. J. Derm., 66, 1-15.

Sjoerdsma, A., and Melmon, K. L. (1964). The carcinoid spectrum. Gastroenterology, 47, 104-107.

- Waalkes, T. P., and Weissbach, H. (1957). Serotonin and histamine in mast cells. Science, 125, 1202-1203.

Stone, J. L., Merrill, J. M., and Meneely, G. R. (1955). The distribution of histamine in human tissues. Fed. Proc., 14, 147-148.

Weber, F. P., and Hellenschmied, R. (1930). Teleangiectasia macularis eruptiva perstans. Brit. J. Derm., 42, 374-382.

Wells, G. C. (1962). Skin disorders in relation to malabsorption. Brit. med. J., 2, 937-943.

Wolf-Jurgensen, P., and Zachariae, H. (1965). Influence of polymixin $B$ and histamine on the cellular exudate in 'skin-windows', Acta derm.-venereol. (Stockh.), 45, 207.

Wulff, H. R., Zachariae, H., and Oehlenschlaeger, K. (1965). The leukocytic response to aseptic inflammation in urticaria pigmentosa. J. invest. Derm., 44, 381-384.

Zachariae, H. (1963). Skin histamine in urticaria pigmentosa. Spectrofluormetric assay. Acta derm-venereol. (Stockh), 43, 125.

- (1964a). Histamine in delayed skin reactions: fluorometric determinations on patch tests. J. invest. Derm., 42, 431-434.

- (1964b). Histamine in human skin. A spectrofluorometric assay. Acta derm.-venereol. (Stockh.), 44, 219.

(1964c). Polymyxin B-induced eosinophilia in chronic urticaria. Ibid., 44, 63.

Zak, F. G., Covey, J. A., and Snodgrass, J. J. (1957). Osseous lesions in urticaria pigmentosa. New Engl. J. Med., 256, 56-59. 